\title{
Distribution and Characteristics of Groundnut Rosette Disease in Kenya
}

\author{
A. W. Wangai, Department of Plant Pathology, S. S. Pappu, Department of Entomology, H. R. Pappu, Department \\ of Plant Pathology, University of Georgia, Coastal Plain Experiment Station, Tifton 31793; C. M. Deom and R. A. \\ Naidu, Department of Plant Pathology, University of Georgia, Miller Plant Sciences Building, Athens 30602
}

\begin{abstract}
Wangai, A. W., Pappu, S. S., Pappu, H. R., Deom, C. M., and Naidu, R. A. 2001. Distribution and characteristics of groundnut rosette disease in Kenya. Plant Dis. 85:470-474.

Groundnut rosette is a major virus disease of peanut in sub-Saharan Africa. The disease is caused by a complex of three agents: GRAV (groundnut rosette assistor luteovirus), GRV (groundnut rosette umbravirus), and the associated satellite RNA (Sat-RNA). During the 1997 to 1998 crop season, the incidence of rosette in farmers' fields was estimated at 24 to $40 \%$ in western Kenya and 30\% in the Rift Valley. Sequence analysis of Kenyan isolates revealed that GRAV-CP sequences shared 97 to $100 \%$ and 95 to $98 \%$ sequence homology at nucleotide and amino acid levels, respectively, amongst themselves and with the Malawian and Nigerian isolates. The ORFs 3 and 4 of GRV were similar, with a homology of $99 \%$ at the nucleotide and amino acid levels among Kenyan isolates. The GRV sequences of Kenyan isolates were closer to the Malawian (95 to $96 \%$ ) than to the Nigerian ( 87 to $88 \%$ ) isolates. Sat-RNA shared 89 to $94 \%$ nucleotide identity with those from Malawi and Nigeria. A closer sequence relationship was observed between Kenyan and Malawian isolates in all regions compared. This is the first report on the distribution and molecular characterization of groundnut rosette disease complex in East Africa.
\end{abstract}

Additional keyword: Arachis hypogaea L.

Groundnut (peanut, Arachis hypogaea L.) is a valuable crop for growers with small holdings in Kenya. As a cash crop it gives relatively high returns for limited land area, and is well adapted to the hot, semi-arid conditions in the regions where it is grown.

Rosette disease on groundnut was first documented at the beginning of the twentieth century in present-day Tanzania and South Africa (6) and since then has been reported in all groundnut-growing regions of sub-Saharan Africa and in Madagascar $(8,9,15,16)$. The disease is caused by a complex of three agents: groundnut assistor luteovirus (GRAV), groundnut rosette umbravirus (GRV), and a satellite RNA (Sat-RNA) associated with GRV (9). Two main symptom types occur, chlorotic rosette $(7,9,16)$ or green rosette (7). Both types of symptoms are attributed to variants of the Sat-RNA. Chlorotic rosette has been the predomi-

Corresponding author: H. R. Pappu

E-mail: hrp@tifton.cpes.peachnet.edu

Permanent address of A. W. Wangai: Kenya Agricultural Research Institute, National Plant Breeding Research Center, P.O. Njoro, Kenya.

Accepted for publication 9 January 2001.

Publication no. D-2001-0201-01R

(C) 2001 The American Phytopathological Society nant form throughout sub-Saharan Africa, whereas green rosette has been reported in west and south Africa and confirmed in east Africa (22).

The impact of rosette disease epidemics on groundnut production is documented in Nigeria and Zambia (9), but information is limited in other African countries where the disease continues to be a major constraint to the small grower. It is now the most destructive virus disease in groundnut, where either symptom type can cause up to $100 \%$ loss in pod yield if the infection occurs before flowering (9). The goal of this work was to determine the distribution of the three disease agents (GRAV, GRV, and SatRNA) responsible for the groundnut rosette disease in Kenya and to determine their variability compared to those from Malawi and Nigeria $(3,4,5,20)$.

\section{MATERIALS AND METHODS}

Field sampling and Virus isolates. A total of 182 plant samples were collected from farm fields in the towns of Kendu Bay, Homa Bay, Kisumu, and Busia in western Kenya, and in the town of Cheplamus in the Rift Valley. Young leaves with characteristic symptoms from natural infection with rosette were harvested from individual plants. The coding system used in the text, table, and figures is as follows: the Kenyan isolates begin with the letter "K," while those from Malawi and Nigeria, used for compartive purposes, begin with the letters " $M$ " and "N," respectively. Suffixes "GCP" and "GCPP" indicate the coat protein portion of the genome (nucleotide and amino acid sequences, respectively) from GRAV. GRV indicates the nucleotide sequences of ORFs 3 and 4 from GRV. "S" indicates the Sat-RNA sequence.

RNA extraction and purification. Approximately $2 \mathrm{~g}$ of leaves were ground into fine powder under liquid nitrogen, then vortexed in $400 \mu$ l of extraction buffer $(2 \%$ SDS, 0.1M Tris-HCl, pH 8.0, 2 mM EDTA) and half volume of phenolchloroform (1:1) mixture. Incubation at $70^{\circ} \mathrm{C}$ for $5 \mathrm{~min}$. was followed by centrifugation at room temperature and the aqueous phase was re-extracted with chloroform alone. The RNA was precipitated in ethanol and the resultant pellet stored in absolute ethanol. Further purification of the RNA was achieved using the RNeasy Mini Kit according to manufacturer's instructions (Qiagen, Chatsworth, CA).

Reverse transcription and polymerase chain reaction (RT-PCR). Primers for specific amplification of nucleic acid sequences from each of the three agents of rosette were shown in Table $1(5,10)$. Using purified total RNA as a template, RT-

Table 1. Primers used in amplification of various regions of causal agents of groundnut rosette disease complex. Primers in the 100 series represent internal primers for specified regions

\begin{tabular}{lccc}
\hline Primers & Sequence & Specific to & Source reference \\
\hline HRP92 & ATGAATACGGTCGTGGTTAGG & GRAV-CP & 5,10 \\
HRP93 & TTTGGGGTTTTGGACTTGGC & GRAV-CP & 5,10 \\
HRP94 & GGAAGCCGGCGAAAGCTACC & GRV ORF3P and 4P & 20 \\
HRP95 & GGCACCCAGTGAGGCTCGCC & GRV ORF3P and 4P & 20 \\
HRP96 & GGTTTCAATAGGAGAGTGC & Sat-RNA & $5,10,14$ \\
HRP97 & AAATGCCTACTTTGGGCGTG & Sat-RNA & $5,10,14$ \\
HRP110 & GGAGGGTCTGGCGAAACATT & GRAV-CP & 5,10 , this study \\
HRP111 & CCCTTGTAAAGGAACCGGAAT & GRAV-CP & 5,10 , this study \\
HRP104 & CGAGGAGACCAAAGGGTGGT & GRV ORF 3P and 4P & 20, this study \\
HRP105 & AGCTCCGACACAATAGCGAAG & GRV ORF 3P and 4P & 20, this study \\
HRP108 & GAAAAGGTGAGGGGTGTGT & Sat-RNA & $5,10,14$, this study \\
HRP109 & TAGCTTGATTTCAAGCTCGC & Sat-RNA & $5,10,14$, this study \\
\hline
\end{tabular}


PCR reactions were set up separately for GRAV, GRV, and Sat-RNA in a two-stage protocol. Five $\mu \mathrm{l}$ of the template were mixed with $200 \mathrm{ng}$ of downstream primers in a total volume of $9.5 \mu \mathrm{l}$, denatured for 10 min at $70^{\circ} \mathrm{C}$ and snap-cooled in ice. A total of $4.5 \mu \mathrm{l}$ of reverse transcription mix $(3 \mu \mathrm{l}$ AMV-RT buffer, $100 \mu \mathrm{M}$ each of the dNTPs [Amersham, Arlington Heights, IL], 20 units Rnasin) was added, mixed well and incubated at $42^{\circ} \mathrm{C}$ for 2 min before adding 15 units of AMV-RT and incubating at $42^{\circ} \mathrm{C}$ for $50 \mathrm{~min}$.

First strand cDNA was amplified by PCR using corresponding $3^{\prime}$ and $5^{\prime}$ primers. The PCR reactions $(100 \mu \mathrm{l})$ contained $2.0 \mu \mathrm{l}$ of the first strand cDNA, $200 \mathrm{ng}$ of the primers, 2.5 units Taq polymerase (Promega, Madison, WI), 1× PCR buffer (Qiagen), 1× Q solution (Qiagen), and 100 $\mu \mathrm{M}$ each of the dNTPs (Amersham Inc.). The amplification consisted of 30 cycles of $45 \mathrm{~s}$ at $90^{\circ} \mathrm{C}, 1 \mathrm{~min}$. at $55^{\circ} \mathrm{C}$ and $1 \mathrm{~min}$. at $72^{\circ} \mathrm{C}$ followed by one final cycle of extension for $60 \mathrm{~min}$. at $72^{\circ} \mathrm{C}$ and was performed in a Perkin Elmer Gene Amp 2400 thermal cycler. PCR products were analyzed on $0.8 \%$ agarose gel in TBE buffer, stained with ethidium bromide, and visualized under UV light. The DNA band of interest was excised and purified using GFX PCR DNA band and Gel Purification Kit (Pharmacia Biotech, Piscataway, N.J.). The purified PCR products were ligated into pGEM-T vector (Promega) and competent Escherichia coli (strain DH5 $\propto$ ) was transformed. The recombinant clones were identified using standard molecular techniques (13). The clones were sequenced at the DNA Sequencing Core Facility of the Interdisciplinary Center for Biotechnology Research, University of Florida, Gainesville. Sequences were aligned, translated, and compared with other published isolates using Seqaid II (12) and CLUSTAL W (21). Cluster dendrograms were generated using the PUZZLE program (17) in PAUP 4.0 (19) and the graphic phylograms were viewed and printed using TreeView (11). GenBank (2) searches were done using the BLAST program (1).

\section{RESULTS AND DISCUSSION}

Field studies. Field studies identified the prevalence of green as well as chlorotic rosette symptoms on the local peanut cultivars. Field infections ranged from 24 to $40 \%$ between the different regions with no variation in the level of infection among cultivars. The average incidence of field infection (both chlorotic and green rosette) was $40 \%$ within the 23 fields sampled in the western region (Homa Bay and Kendu Bay). Chlorotic rosette symptoms were found to be severe in Kendu Bay and Homa Bay. In the Rift Valley regions (Cheplamus, Marigat areas), average disease incidence was $30 \%$ in the eight fields sampled. In the Kisumu and Busia regions, the disease symptoms were not as severe and the incidence was $24 \%$, possibly due to later infection when the crop was near flowering stage.

The groundnut crop sampled was between the flowering and physiological maturity stage in the four most popular cultivars grown: Homa bay local, Homa bay grade, Nyaela red, and Nyaela white, as well as in the other local cultivars. All the cultivars had chlorotic symptoms but there was no variation in the percentage infection among the cultivars observed. Green rosette was observed on groundnut cultivars Nyaela red and Homa bay local in the Kendu Bay region, comprising 5.3\% of the plants with rosette symptoms.

RT-PCR detection and nucleotide sequence of GRAV-CP. Using primers specific to the GRAV-CP genes, a $597 \mathrm{bp}$ fragment was amplified from six samples (K25GCP, K37GCP and K39GCP from Rift Valley; K1GCP, K2GCP, and K46GCP from western Kenya) and the nucleotide sequences obtained were com- pared to published sequences. Nucleotide identity among the samples from Kenya was 97 to $100 \%$, and when compared to the Malawi isolate of Taliansky et al. (20), a nucleotide identity of 96 to $97 \%$ was observed. There was a high degree of sequence identity (96 to $98 \%$ ) between the Kenyan and the other Malawian and Nigerian isolate nucleotide sequences of Deom et al. (5). Among the Kenyan isolates, K1 and $\mathrm{K} 2$ were closer in sequence relationship compared to those from the Rift Valley region (K37GCP, K39GCP, and $\mathrm{K} 25 \mathrm{GCP}$ ) and the one from Busia (K46GCP) near the Kenya-Uganda border with the latter sequences (K25, K37, K39, and K46) clustering together. Amino acid similarities were comparable to those observed at the nucleotide level among the Kenyan, Malawian, and Nigerian isolates. K1GCP and K2GCP from western Kenya were nearly identical with $99 \%$ amino acid sequence identity, while exhibiting $97 \%$ sequence homology with the other isolates.

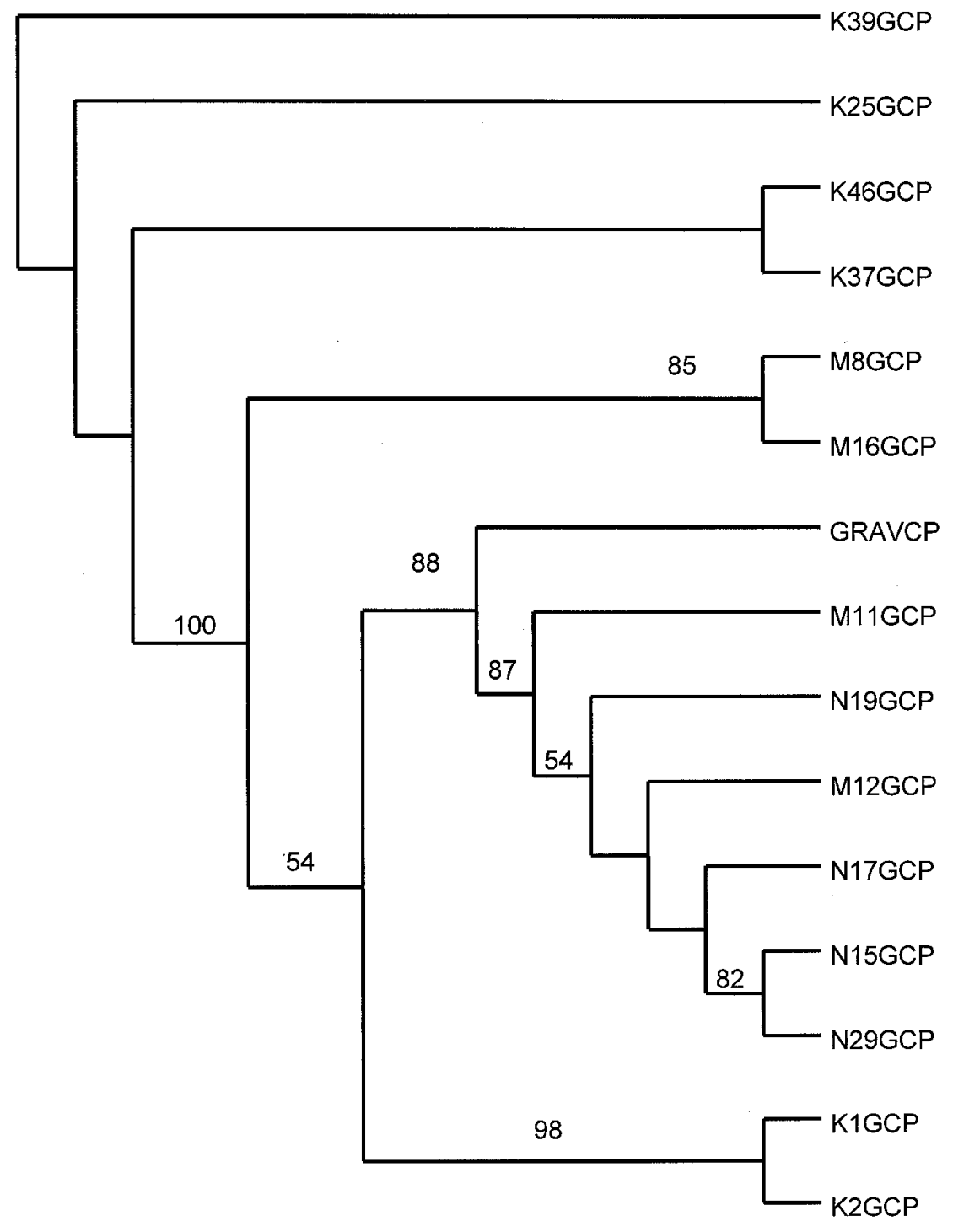

Fig. 1. Dendrograms of the groundnut rosette assistor virus isolates from Kenya, Malawi $(5,14)$ and Nigeria (5), derived from the coat protein gene nucleotide sequences. Isolates are labeled by geographical origin: "K" = Kenya, "M" = Malawi, and "N" = Nigeria. 
The amino acid sequences were identical among the samples from the Rift Valley (K25, K37, and K39). A phylogenetic dendrogram (Fig. 1) indicated the nucleotide similarities among the isolates from Kenya compared with those from Malawi and Nigeria. All the Kenyan isolates from the Rift valley (K25, K37, and K39) and K46 from western Kenya grouped together and were distinct from the previously published sequences of Malawian and Nigerian isolates (Fig. 1). Isolates $\mathrm{K} 1$ and $\mathrm{K} 2$ from western Kenya exhibited a closer sequence relationship with the Malawian isolates, M8 and M16 than with other Malawian isolates (N15, N17, N19, and N29; Fig. 1). Although the phylogram indicates that the $\mathrm{CP}$ sequences are not diverging based on geographical origin, closer examination reveals a definite pattern, particularly in the amino acid sequence cladogram (Fig. 2). All the Nigerian isolates clustered together and the Malawian and Kenyan isolates appear to be diverging as a group from the Nigerian isolates.

RT-PCR detection and nucleotide sequence of GRV ORF 3 and 4. A fragment 865bp long was amplified from three isolates from Kenya (K10GRV, K11GRV, and (M11, M12, and GRAV-CP) and Nigerian

K14GRV) using primers HRP94 and HRP95, specific to GRV ORF3 and 4. Sequence comparisons indicated that the percentage of nucleotide identity within the Kenyan isolates was $99 \%$ for the sequenced region, whereas the nucleotide identity between the Kenyan isolates and the published Malawian isolate (20) was 88 to $89 \%$ for both ORFs 3 and 4 . When the Kenyan GRV sequences were compared with the GRV sequences of the other Malawian and Nigerian isolates (5; Fig. 3), the percent nucleotide homology was higher with the GRV sequences of the Malawian isolates (95 to $96 \%$ ), while the Nigerian isolates exhibited a sequence identity of 87 to $88 \%$ with the GRV sequences of the Kenyan isolates K10, K11, $\mathrm{K} 14$. At the amino acid level, similar sequence relationships were exhibited by the Kenyan, Malawian, and Nigerian isolates. When the ORF3 and ORF4 protein sequences were compared separately, the sequence of ORF3 protein of the Kenyan isolates appeared more divergent compared to that of the ORF4 protein. This is consistent with the findings of Deom et al. (5). The ORF4 protein sequence had a higher level of sequence homology (95 to 97\% with the Malawian and 91 to $92 \%$ with the

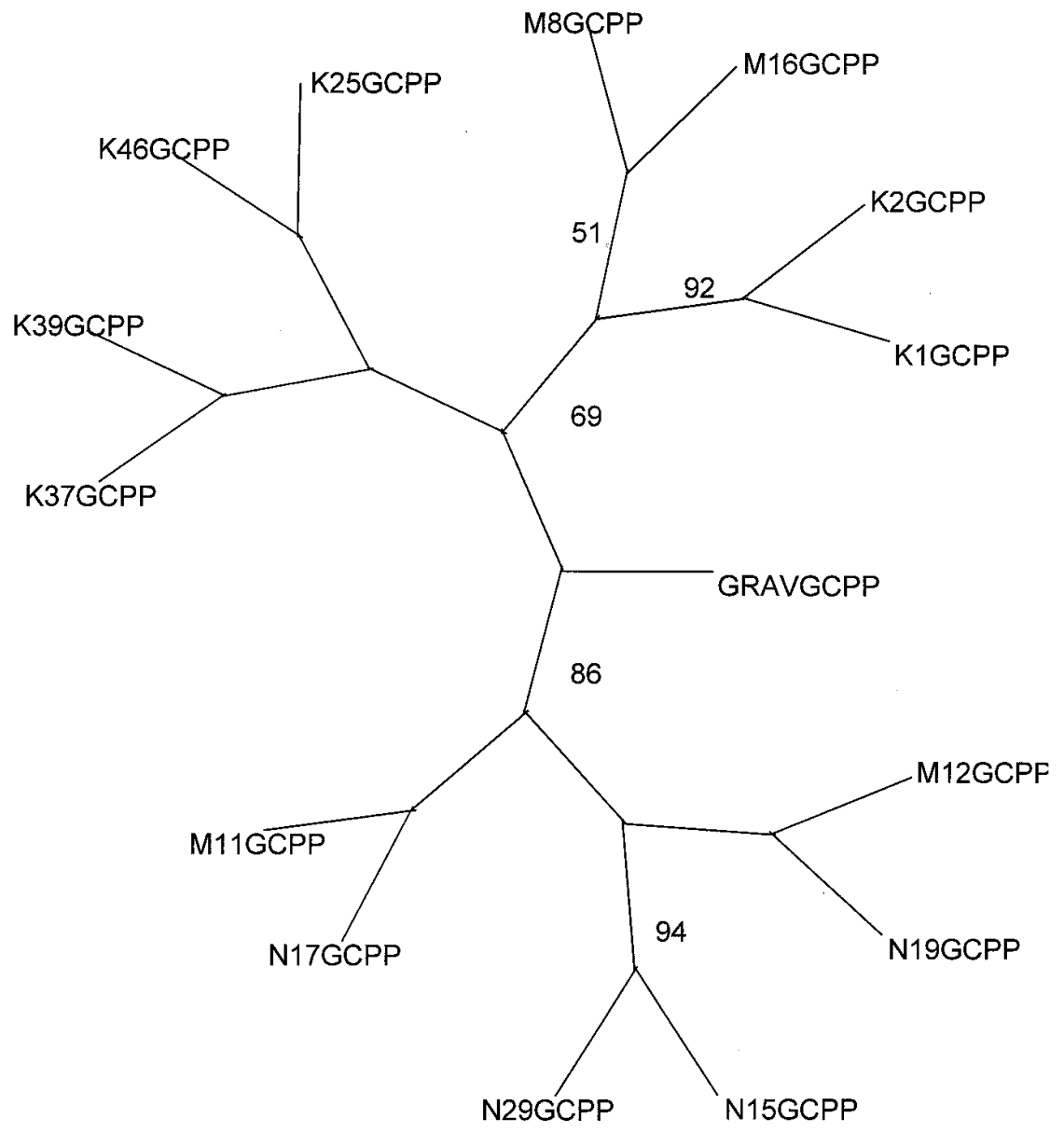

Fig. 2. Dendrograms of the groundnut rosette assistor virus isolates from Kenya, Malawi $(5,14)$ and Nigeria (5), derived from the coat protein amino acid sequences. Isolates are labeled by geographical origin: "K" = Kenya, "M" = Malawi, and "N" = Nigeria.
Nigerian ORF4 protein sequences) with its corresponding sequences from Malawi and Nigeria compared to the ORF3 protein (89 to $92 \%$ with the Malawian and 72 to $75 \%$ with the Nigerian ORF3 protein sequences).

The predicted amino acid sequence of the ORF3 protein of the Kenyan isolates was nine amino acids longer than the ORF3 protein sequence given for the published Malawian isolate sequence (20). Furthermore, the predicted amino acid sequence for the three Kenyan isolates was two amino acids shorter than those of Deom et al. (5). Examination of the nucleotide sequence from the $\mathrm{N}$-terminal region of ORF3 protein revealed that the difference in the amino terminal sequence of the ORF3 protein was due to the variation in the start codon position in all the sequences considered (data not shown). The Malawian and Nigerian sequences (5) retained two of the three possible start codon positions (positions 25 and 31 of the sequenced region) while the Kenyan isolates have only one possible start at position 31 of the sequenced region (data not shown). While the Malawian and Nigerian isolates (5) seem to have a start codon at position 25, the ORF3 of Kenyan isolates has a start codon at position 31 . The ORF3 of Taliansky et al. (20) seems to begin at position 58, although the position 31 also has a start codon. The ORF3 sequence region (20) does not have a start codon at position 25. Thus the initial few amino acids of the Kenyan sequences were MVEHL and are presumably shorter by two amino acids compared to the Malawian (MDMVEHL) and Nigerian sequences (MDMAQHP; 5).

A phylogenetic dendrogram (Fig. 3) showed that the nucleotide sequences from Kenya were highly similar and clustered together, but distinct from the isolates from Malawi and Nigeria. Comparison of the nucleotide and amino acid sequences of all the isolates indicated that the Kenyan isolates were closer to the Malawian isolates of Deom et al. (5) than to those from Nigeria (5) and the Malawian isolate of Taliansky et al. (20). The sequence comparisons indicated that more variation originated in ORF3 than ORF4. The GRV sequences of all the isolates compared indicated that the GRV sequence conservation follows the geographic origin of an isolate.

RT-PCR detection and nucleotide sequence of Sat-RNA. Comparison was made between the Sat-RNA sequence obtained from western Kenyan isolate K10S and published sequences from Malawi and Nigeria. All published sequences shared nucleotide identity with the Kenyan isolate, the highest identity being at 95\% (M24S) and the lowest at 89\% (NG3a) (Fig. 4). A closer sequence relationship was observed between the Kenyan SatRNA sequence and its Malawian counterparts than with the Nigerian Sat-RNA se- 
quences. The seven nucleotide deletion seen (5) in the case of the two Sat-RNA sequences-one Malawian (M11S) and one Nigerian (N310S) - is absent in the Kenyan isolate. The two elements (element A:280-470 nucleotides and element B:629849 nucleotides) suggested to be involved in symptom production were well conserved in the Kenyan isolate when compared to its Malawian and Nigerian counterparts (data not shown). A cluster dendrogram indicated that the Nigerian isolates are clustered in one group, while isolates from Malawi formed a distinctively separate cluster (Fig. 4). The isolate from Kenya (K10S) was closer to the Malawian than to the Nigerian isolates.

The full impact of the endemic of rosette disease on groundnut production and the socio-economic well being of the small farmer in Kenya has not been documented. Although there are some genotypes of groundnut known to have a good level of resistance to chlorotic rosette disease, none of the cultivars identified so far have resistance to GRAV. It is unclear whether resistance to groundnut rosette disease, which has been conferred by double recessive genes, will remain stable and effective in all genotypes (18). Alternative breeding strategies, such as use of wild species of Arachis and conferring of resistance to GRAV through incorporation of the $\mathrm{CP}$ gene, offer promising strategies for development of effective and sustainable management of rosette disease in Africa (18).

Although some information is available on the molecular characteristics of GRDcausing agents from western and southern Africa, this is the first report on the incidence and molecular characterization of groundnut rosette-causing agents from east Africa. Nucleotide sequences of GRAV-CP gene from isolates collected from western Kenya, which borders Uganda, are distinct from those from the central region of the country (Rift Valley) (Fig. 1). Because groundnut is an important crop in eastern Uganda it would be interesting to determine whether isolates from eastern Uganda, which have not been characterized, are similar to those from western Kenya. The high degree of homology of the GRAV-CP gene sequences from eastern Africa with those from southern and western parts of the continent could have the potential to be exploited in the development of transgenic plants with resistance that can be used across sub-Saharan Africa.

\section{ACKNOWLEDGMENTS}

A. W. Wangai was supported by a Fulbright Research Fellowship. S. S. Pappu was supported by a post-doctoral fellowship from University of Georgia's College of Agricultural and Environmental Sciences. We thank the Agency for International Development-Peanut Collaborative Research Support Program (Grant LAG-G-00-96-90013-00) and the Rockefeller Foundation (Grant AS 9827) for supplementary funding, and the International Center for Insect Physiology and Ecology, Kenya, for providing facilities.

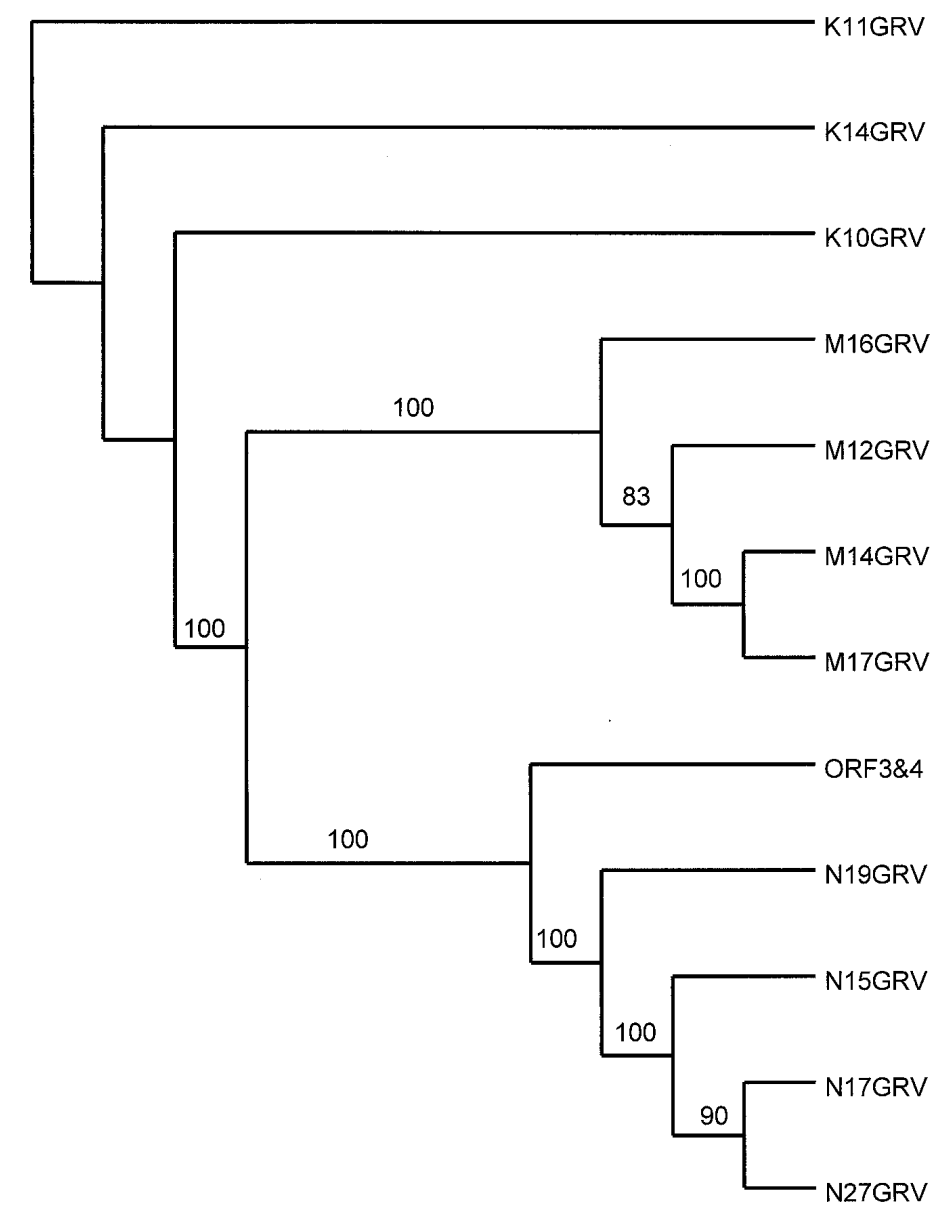

Fig. 3. A dendrogram derived from nucleotide sequences of the groundnut rosette virus ORFs 3 and 4 of isolates from Kenya, Malawi $(5,20)$, and Nigeria (5). Isolates are labeled by geographical origin: "K" = Kenya, "M" = Malawi, and "N" = Nigeria.

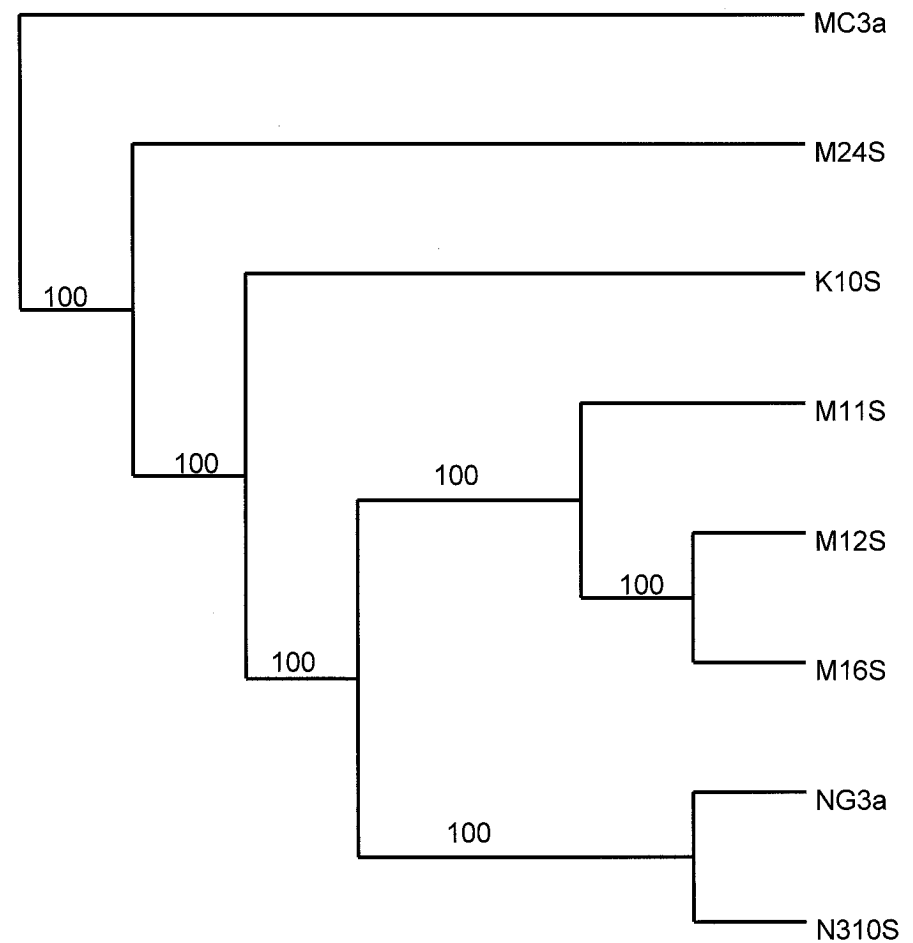

Fig. 4. A dendrogram derived from satellite RNA nucleotide sequences of isolates from Kenya (K10S) and those from Malawi (5) and Nigeria $(3,5)$. Isolates are labeled by geographical origin: "K" = Kenya, "M" = Malawi, and "N" = Nigeria. 


\section{LITERATURE CITED}

1. Altschul, S. F., Gish W., Miller W., Myers, E. W., and Lipmon, D. J. 1990. Basic local alignment tool. J. Mol. Biol. 215:403-410.

2. Benson, D. A., Boguski, M. S., Lipman, D. J., Ostell, J., Ouellette, B. F., Rapp, B. A., and Wheeler, D. L. 1999. GenBank. Nucl. Acids Res. 27:12-17.

3. Blok, V. C., Ziegler A., Robinson D. J., and Murant A. F., 1994. Sequences of 10 variants of the satellite-like RNA-3 of groundnut rosette virus. Virology 202:25-32.

4. Blok, V. C., Ziegler A., Scott K., Dangora D. B., Robinson D. J., and Murant A. F., 1995. Detection of groundnut rosette umbravirus infections with radioactive and non-radioactive probes to its satellite RNA. Ann. Appl. Biol. 127:321-328.

5. Deom, C. M., Naidu, R. A., Chiyembekeza, A. J., Ntare, B. R., and Subrahmanyam, P. 2000. Sequence diversity within the three agents of groundnut rosette disease. Phytopathology 90:214-219.

6. Hayes, R. T. 1932. Groundnut rosette disease in Gambia. Trop. Agric. 9:211-217.

7. Murant, A. F., Rajeshwari, R., Robinson, D. J., and Raschke, J. H., 1988. A satellite RNA of groundnut rosette virus that is largely responsible for symptoms of groundnut rosette disease. J. Gen. Virol. 69:1479-1486.

8. Naidu, R. A., Bottenberg, H., Subrahmanyam, P., Kimmins, F., Robinson, D. J., and Thresh, J. M. 1998. Epidemiology of groundnut ro- sette virus disease: Current status and future research needs. Ann. Appl. Biol. 132:525548.

9. Naidu, R. A., Kimmins, F. M., Deom, C. M., Subrahmanyam, P., Chiyeubekeza, A. J., and van der Merwe, P. J. A. 1999. Groundnut Rosette: A virus disease affecting groundnut production in sub-Saharan Africa. Plant Dis. 83:700-709.

10. Naidu, R. A., Robinson, D. J., and Kimmins, F. M. 1998. Detection of each of the causal agents of groundnut rosette disease in plants and vector aphids by RT-PCR. J. Virol. Methods. 76:9-18.

11. Page, R. D. M., 1996. TreeView: An application to display phylogenetic trees on personal computers. Comp. Appl. Biosci. 12:357-58.

12. Rhoads, D. D., and Roufa, D. S. 1985. Emetine resistance of Chinese hamster cells: Structure of mutant ribosomal protein S14 messenger RNA species. Mol. Cell. Biol. 5:1655-1659.

13. Sambrook, J., Fritsch, E. F., and Maniatis, T. 1989. Molecular cloning: A Laboratory Manual. Cold Spring Harbor Laboratory. New York.

14. Scott, K. P., Farmer, M.-J., Robinson, D. J., Torrance, L., and Murant, A. F. 1996. Comparison of the coat protein of groundnut rosette assistor virus with those of other luteoviruses. Ann. Appl. Biol. 128:77-83.

15. Storey, H. H., 1935. Virus Disease of East African Plants: III Rosette Disease of
Groundnuts. East Afr. Agric. J. 1:206-211.

16. Storey, H. H. and Bottomley, A. M. 1928 Rosette disease of the peanut (Arachis hypogaea L.). Ann. Appl. Biol. 15:26-45.

17. Strimmer, K., and von Haeseler, A. 1997. Quartet puzzling: A quartet maximum likelihood method for reconstructing tree topologies. Mol. Biol. Evol. 13:964-969.

18. Subrahmanyam, P., Hilderbrand, G. L., Naidu, R. A., Reddy, L. J., and Singh, A. K. 1998. Sources of resistance to groundnut rosette disease in global groundnut germplasm. Ann. Appl. Biol. 132:473-485.

19. Swofford, D. L. 1998. PAUP: Phylogenetic analysis using parsimony and other methods. Version 4. Sinauer Associates, Sunderland, MA.

20. Taliansky, M. E., Robinson, D. J., and $\mathrm{Mu}-$ rant, A. F. 1996. Complete nucleotide sequence and organization of the RNA genome of groundnut rosette umbravirus. J. Gen. Virol. 77:2334-2345.

21. Thompson, J. D., Higgins, D. G., and Gibson, T. J. 1994. CLUSTAL W: Improving the sensitivity of progressive multiple sequence alignment through sequence weighting, position-specific gap penalties and weight matrix choice. Nucleic Acids Res. 22:4673-4680.

22. Wangai, A. W., Pappu, S. S., Pappu H. R., Okoko N., Deom C. M., and Naidu, R. A. 1999. First report of the green rosette variant of groundnut rosette disease in Kenya. Plant Dis. 83:782. 